\title{
Management for Improving the Quality of Student Learning in Primary Schools
}

\author{
Susri Maryati \\ SDN Sugi Waras \\ e-mail: susrimaryati1234@gmail.com \\ Syarwani Ahmad \\ Universitas PGRI Palembang \\ e-mail: syarwaniahmad@univpgri-palembang.ac.id \\ Syaiful Eddy \\ Universitas PGRI Palembang \\ e-mail: syaifuleddy@gmail.com \\ Article History: Received on 13 January 2021, Revised on 20 January 2021, \\ Published on 22 January 2021
}

\begin{abstract}
This study determined the implementation of learning management used by teachers in improving student achievement. The data collection methods are observation, interview and documentation, then checking the validity of the data by comparing the information provided by the informant and the observation data with the results of the interview, then the data is analyzed qualitatively. From the results of the study, it was found that: 1) the implementation of learning management by teachers in improving student achievement was carried out by identifying, objectives, benefits, planning steps, planning stages, including indicators or quality targets to be achieved as a process of increasing learning achievement students in order to realize the quality of education; 2) the inhibiting factor for the implementation of learning management at SDN in Babat Toman Subdistrict, Musi Banyuasin Regency, namely the lack of awareness of teachers to compile lesson plans, many students are passive in implementing learning even though they have been given a stimulus by the teacher and the lack of variation in assessments carried out by the teacher and too many students so the time allocation for conducting the assessment is insufficient or difficult; 3) a solution to overcoming obstacles, namely by conducting trainings on how to compile a good syllabus and lesson plans applying learning strategies that are evaluated by varying assessment techniques.
\end{abstract}

Keywords: Learning Management, Quality of Education, Learning Achievement

\section{A. Introduction}

Quality schools are believed to be institutions that are responsible within the framework of the intellectual life of this nation that will always be seen and become the focus of public attention. Schools are an inseparable part of what happens in the community. Thus, as a learning community in the wider society schools will always be in the midst of a vortex of change that occurs in the community and vice versa.

It is pointed out that the main obstacle in improving the quality of education lies in the process of school management and learning which does not develop professionally (Suyanto and 
Abbas, 2001). In the aspect of teachers, students, and teaching materials are the dominant elements in the learning process in the classroom. Any program that will be carried out in an effort to improve the quality of education will be difficult to achieve if the school management conditions are still unable to develop into a more professional direction. The ability of teachers to attract students' interest in learning is the initial stage of a meaningful learning process that can make students active and motivated to develop all abilities in the classroom. Professional teachers arebelieved to be able to make student think, behave an act creatively (Ruslan et al, 2020). Professional teachers are the main keys to smooth and successful learning. Because only professional teachers can create an active situation for students in learning activities. Professional teacher believed to be able to deliver students in learning to find, manage, integrate their acquisition, and solve problems related to knowledge, attitudes, and values or life skills. The less than optimal performance of teachers in schools is not entirely caused by the ability of the teachers themselves (Maryati et al, 2020).

Therefore, local governments should not underestimate the importance of a strategy for developing and developing superior human resources in the regions by optimizing school restructuring, both in the management and curriculum fields. The availability and support of superior human resources is very important to be fulfilled so that the community can achieve progress through sustainable development (Syafaruddin, 2002). Quality human resources can be realized with a good educational process and from quality educational institutions (Rahmadoni, 2018; Asvio et al, 2019).

In principle, the primary schools in Babat Toman Subdistrict, Musi Banyuasin Regency as educational units will not become of good quality or superior by themselves, but through various efforts for the quality of their education. Here the principal of primary schools together with other stakeholders are trying to do something, changing the "status quo" so that schools are also better (Bafadal, 2012). The principal as the leader of the educational institution functions as the person in charge of all educational activities in the school (Agustina et al, 2021). If there are good primary schools, in addition to many bad elementary schools, it can be observed how these good schools carry out various quality improvement programs, various changes, and various reforms. The leadership of the principal is very supportive of achieving effective and efficient school management.

A person in a leadership position has the ability to read the situation to be faced and adjust his leadership style to the demands of the situation he is facing, even though this adjustment is only temporary (Astuti et al, 2020). Leadership includes three meanings, namely effort, the ability to run a business, and an authority that makes someone considered capable of leading. Institutional leaders must be able to play an active role and be able to strategically position themselves in directing the institution. The success and effectiveness of a school principal in leading can be pursued by respecting each other, working together and having knowledge about the behavior of subordinates (Rahmadoni, 2018).

\section{B. Methods}

This type of research used in this research is qualitative research, with a qualitative descriptive approach which is to explore objects. This research also produces descriptive data describing the implementation of management of learning quality improvement at SDN in 3 schools in Babat Toman District, Muba Regency. 
Volume 1 (3) 2020

E-ISSN: 2723-6919 P-ISSN:2746-0827

Because this research is a qualitative research, the researchers determined the informants as research subjects who are more suitable for use in this study, namely in addition to the researchers interviewing the principal, the researchers also took several informants from several class teachers and students at SDN 1 Babat Toman. SDN Sugi Waras and SDN Sereka in Babat Toman sub-district, Muba Regency.

Data obtained through observation or observation, interviews and documentation. After the data can then be analyzed as explained by Miles and Huberman in Sugiyono (2015) namely: (1) data reduction; (2) data presentation or display, and (3) conclusions.

\section{Results and Discussion}

\section{Implementation of Learning Management Used by Teachers to Improve Student Learning Achievement)}

\section{a. Planning for Improving Learning Achievement in order to Achieve Quality Education}

In relation to improving student learning achievement in order to realize the quality of education at SD 1 Babat Toman, SDN Sugi Raya and SDN Sugi Waras each school principal by setting standards for the quality of graduates, teacher quality and service quality. The activities of preparing management planning for improving the quality of education at SD 1 Babat Toman, SDN Sugi Raya and SDN Sugi Waras can be carried out by including: (1) programming; (2) schedule of activities, and (3) arranging the amount of budget and resources and so on. All these plans depart from the contents of the attachment contained in the vision and mission of SD. Standardization of the quality of education carried out by referring to technical guidelines and implementation instructions from the Youth and Sports Education Office include: 1) organizing the National Final Examination; 2) conducting deepening of material in the form of study guidance or also called intensive in the subjects contained in the National Final Examination; 3) participating in Try Outs organized by schools, the Education Office as well as Try Outs held or organized by private agencies; 4) organizing Porseni activitie, and 5) organizing and participating in teacher data collection activities to attend the training.

The policy adopted is a policy formulated by the principal and with discussion to teachers in order to achieve good learning achievement in realizing the quality of education in elementary schools in general through increasing intracurricular and extracurricular activities aimed at training students' academic and practical abilities.

In the preparation of plans that will be applied to management activities or programs to increase student learning achievement in order to realize the quality of education at elementary schools, the principal has several documents that become the basic reference in planning programs and activities in improving student learning achievement in order to realize the quality of education in elementary schools, among others. others: standard content of BSNP and content standard of Kepmendiknas No. 22 of 2006, Law of the Republic of Indonesia No. 20 of 2003 concerning the national education system and the Republic of Indonesia Government Regulation No.19 of 2005 concerning National Education Standards.

In this study, it was found that the planning of increasing student learning achievement in order to achieve a quality education quality was carried out by the principal in its implementation that was carried out well and harmoniously. Planning to improve the quality of education at 
SDN 1 Babat Toman, SDN Sugi Waras and SDN Sugi Raya is carried out by considering related aspects. The planned form of planning takes the form of planning human resources, financial resources (funds) and infrastructure and infrastructure resources as well as its development. The formulation of planning for improving the quality of education at SDN 1 Babat Toman, SDN Sugi Waras and SDN Sugi Raya is carried out through deliberations involving all important components in an organization, including: school principals, teachers, employees, school committees. The teacher will show an interest in following a task or activity and then carry it out well, if there is a driving factor, namely motivation (Darmiati et al, 2020). In the continuity of this deliberation, the principle of participation is used to provide suggestions and positive ideas that can be applied in planning to improve student learning achievement in order to realize the quality of education at SDN 1 Babat Toman, SDN Sugi Waras and SDN Sugi Raya.

\section{b. Organizing Resources in Improving Learning Achievement to Achieve Quality Education}

In an organization there is a direction which is interpreted by the Principal as an activity to invite, persuade and influence all elements of the school, both educators, and staff employees to contribute through cooperation in achieving organizational goals. Direction through giving directions or providing an overview of the activities to be carried out so that managers must be able to motivate staff and organizational personnel to maximally and voluntarily carry out activities as a manifestation of the plans that have been prepared.

Organizing also contains an element of coordination where with the coordination in applying the elements of an organization they will be interconnected and they show a linkage in such a way that everyone who takes the right action at the right time in order to achieve the goal. In every complex organization such as a school, each division must work in coordination so that each can produce what is expected.

Organizing the improvement of student learning achievement in order to realize the quality of quality education at SDN 1 Babat Toman, SDN Sugi Waras and SDN Sugi Raya is carried out by detailing all tasks, work that must be carried out and done by every personnel in the school organization SDN 1 Babat Toman, SDN Sugi Sane and SDN Sugi Raya in terms of achieving the planned goals. The division of the burden of duties and responsibilities into activities that can be carried out by each individual by coordinating their implementation with personnel members so that it becomes an integrated and harmonious unit in an organizational management. Organizing has created the basis for mutually supportive cooperation between management personnel in achieving school goals.

\section{c. Implementation of the Management Program for Improving Learning Achievement in order to Achieve Quality Education}

Implementation is often also mentioned as moving and stimulating all individuals or school organization personnel to carry out their tasks enthusiastically and with good ability. In other words, that the task of carrying out or mobilizing is carried out and coordinated by the principal as the highest chair in an organization as well as policy makers in the context of operational implementation or activation carried out in areas that have been delegated and given authority and in the context of classroom teachers who are responsibility in the learning process that must have the ability and a very important role in implementing or mobilizing the people 
Volume 1 (3) 2020

E-ISSN: 2723-6919 P-ISSN:2746-0827

involved in implementing teaching and learning programs at school institutions. Professional teachers have social responsibility manifested through teacher competence from the social environment and have effective interactive skills.

Implementation or activation carried out by the principal as instructional leader while the educator as the leader in the learning process includes several stages, including: (1) compiling the time frame and costs required for both agency needs and the need for the process of implementing learning activities in detail and clearly, (1) 2) initiating and displaying leadership in implementing plans and making decisions and policies that have been set, (3) providing good instructions or direction specifically towards achieving goals, and (4) guiding, motivating and supervising teachers by the principal.

The implementation of increasing student learning achievement in order to realize the quality of quality education at SDN 1 Babat Toman, SDN Sugi Waras and SDN Sugi Raya has not been fully implemented optimally in activities that support the achievement of goals, namely increasing learning achievement in order to achieve quality education quality. Planning carried out at the beginning of the new academic year that has been partially compiled has met the standards and management demands for increasing student learning achievement in order to realize the quality of education, one of which is planning that includes most of the activities and programs to improve the quality of education at SDN 1 Babat Toman, SDN Sugi Waras and SDN Sugi Raya.

A teacher is required to realize quality education. Performance issues are always a major concern in educational institutions / schools because they affect the productivity of these schools. This is as expressed by Yuliandri and Kristiawan in their article entitled "The Role of Principal Leadership in Improving Teacher Performance" (2016) teacher performance can be interpreted as the level of teacher success in carrying out educational tasks in accordance with their responsibilities and authorities based on work standards that have been set for a certain period in order to achieve educational goals. Teacher performance standards relate to the quality of teachers in carrying out their duties such as: (1) working with students individually, (2) preparing and planning lessons, (3) using learning media, (4) involving students in various learning experiences, and (5) effective leadership from teachers. Teacher performance will be optimal if it is integrated with school components, whether it is the principal or students.

The implementation of the management program in the form of activities has implemented plans that have been prepared, even in implementation, namely increasing student learning achievement in order to realize the quality of education by implementing Mathematics, Indonesian Language every week and being carried out every month in the form of a Try Out program for fourth grade students, five and six. Development of Islamic religious education in the form of tahsin, increasing understanding and strengthening of religious education through teaching and learning processes and the implementation of prayer, dhikr and memorization of Asmaul Husna.

\section{d. Supervision in the Improvement of Learning Achievement in order to Achieve the Quality of Education}

As one of the management functions, supervision is the last action taken by managers in an organization to ensure that organizational and management goals are achieved. With 
supervision, it is hoped that deviations in various ways can be avoided. Besides, the monitoring process will ensure standards for achieving goals. The results of interviews with several educators stated that the supervisory process carried out by the Principal was direct and related to teaching activities carried out in the form of classroom supervision of education during the learning process.

With the guidance in the implementation of supervision carried out by the principal. In terms of supervision, it is basically carried out by the principal as the policy maker, but this cannot be separated from the coordination and cooperation between personnel in an organization to inform each other about anything aimed at achieving common goals.

Supervision in this form is a process where certain aspects of a procedure must be adjusted to the planning that has been implemented. The suitability of planning with implementation will be a measure for the achievement of goals. Besides that, in this supervision, there will be weaknesses in human resources (educators) as well as a lack of infrastructure that functions as a support in activities to increase learning achievement in order to realize the quality of education.

\section{Inhibiting Factors for the Implementation of Learning Management in SDNs in Babat Toman District, Musi Banyuasin Regency}

As for the inhibiting factors in learning management at SDN 1 Babat Toman, SDN Sugi Waras and SDN Sugi Raya, among others: (1) Inhibiting factors for learning planning, namely the lack of teacher awareness to prepare lesson plans, (2) inhibiting factors for the implementation of learning, namely many students which is passive in the implementation of learning even though it has been given a stimulus by the teacher, (3) The inhibiting factor in the evaluation of learning is that too much preparation is made in the assessment plus the number of students is quite large.

The factor that hinders learning planning, the most dominant factor is the lack of awareness of teachers to prepare lesson plans. While the factors that hinder the implementation of learning data show that many students are passive in the implementation of learning even though they have been given a stimulus by the teacher. Besides that, many students also get bored if they hold discussions every day. These factors appear as natural reactions of students who are experiencing the learning process.

\section{Solutions to Overcome Barriers in Learning Management Implementation}

The solutions for overcoming the barriers to learning management in improving student learning achievement in order to realize the quality of education at SDN 1 Babat Toman, SDN Sugi Waras and SDN Sugi Raya are quite good, to solve existing problems according to Mulyasana (2011) including: 1) solution of inhibiting factors for learning planning, to overcome the difficulties of teachers in planning lessons, trainings are conducted on how to compile a good syllabus and lesson plans. So that teachers can compile a good syllabus and lesson plans, teachers should be able to recognize and identify what characterizes the school and its area. There must be guidelines for the preparation of syllabus and lesson plans, both general and local. Teachers' understanding of local peculiarities requires socialization with the local government, education offices and schools. The local government should determine what the local advantages of the area will be which will be included in the education program;2) 
solution of inhibiting factors for the implementation of learning, the solution that can be applied to overcome the obstacles in implementing learning is to implement a learning strategy. The learning strategy that can be carried out by the teacher is to emphasize more on student activities. The learning method used requires the activity of various levels of student ability. The level of student ability is demanded not only at a low level, for example the ability to memorize. Various thinking skills can be developed, for example, the ability to think critically by using the discussion method, the ability to do research or observation using the project method, the affective ability using the role player method or socio-drama, and other examples. In order for teachers to master various teaching methods, it is necessary to conduct training on various teaching methods, and 3) solution of inhibiting factors in learning evaluation, that can be applied in overcoming natural barriers to learning evaluation is by varying assessment techniques. Teacher-developed assessments are not limited to test users only. Teachers use various models of assessment tools, such as performance assessments, portfolios, and other types of non-test assessments. Determination of the use of the assessment tool depends on the formulation of the objectives that have been set. Various skills can be developed, for example social skills using attitude scale assessment tools, research skills using portfolio assessment, and others.

\section{Conclusion}

From the results of the study it can be concluded that: 1) the implementation of learning management used by teachers in improving student learning achievement is carried out by identifying, objectives, benefits, planning steps, planning stages, including indicators or quality targets to be achieved as a process increasing student achievement in order to realize the quality of education. The form of planning is carried out by the principal by providing guidance, assistance, supervision and assessment on problems related to the technical implementation and development of teaching education in the form of improving teaching education programs and activities to be able to create teaching and learning situations. Meanwhile, the teacher evaluates learning through process assessment and results assessment. Process assessment is carried out on the participation of students both individually and in groups during the learning process; 2) assessment of results is carried out at the middle and end of the semester; 1 . Inhibiting factors for the implementation of learning management in SDN in Babat Toman District, Musi Banyuasin Regency, it is found that: a) the inhibiting factor for planning is due to the lack of awareness of teachers to prepare lesson plans; b) the inhibiting factor for the implementation of teaching is that many students are passive in the implementation of learning even though they have been given a stimulus by the teacher, and c) the inhibiting factor in the Learning Evaluation is the lack of variation in the assessment carried out by the teacher. Then the number of students is too large so that the time allocation for conducting assessments is insufficient or difficult to do, and 3) solutions to overcome obstacles in the implementation of student management at SDN in Babat Toman District, Musi Banyuasin Regency: a) carried out with trainings on how to compile a good syllabus and lesson plans; b) implementing learning strategies. The learning strategy that can be carried out by the teacher is to emphasize more on student activities. The learning method used requires the activity of various levels of student ability; c) by varying the assessment techniques. Teacher-developed assessments are not limited to test users only. Teachers use various models of assessment tools, such as performance assessments, portfolios, and other types of non-test assessments. 


\section{E. Acknowledgement}

We thank to the Principal of SDN Sugi Waras, Chancellor of the Universitas PGRI Palembang, Director of Graduate Program and the Education Management Study Program who have supported us to do this project. This project is independently funded. We would also like to thank our friends in who helped us a lot in completing this project.

\section{References}

Agustina, M., Kristiawan, M., \& Tobari. (2021). The Influence of Principal's Leadership and School's Climate on The Work Productivity of Vocational Pharmacy Teachers in Indonesia. International Journal of Educational Review 3(1), 63-76.

Astuti, R. W., Fitria, H., \& Rohana, R. (2020). The Influence of Leadership Styles and Work Motivation on Teacher's Performance. Journal of Social Work and Science Education, 1(2), 105-114. Retrieved from https://ejournal.karinosseff.org/index.php/jswse/article/view/33

Asvio, N., Yamin, M., \& Risnita. (2019). Influence of Leadership Style, Emotional Intelligence and Job Satisfaction toward Organizational Commitment (Survey at SMA Muhammadiyah South Sumatera). International Journal of Scientific \& Technology Research 8 (8).

Bafadal, I. (2012). Manajemen Peningkatan Mutu Sekolah Dasar: Dari Sentralisasi Menuju Desentralisasi [Management of Quality Improvement in Primary Schools: From Centralization to Decentralization]. Jakarta: PT Bumi Aksara.

Darmiati, D., Kristiawan, M., \& Rohana, R. (2020). The Influence of School Leadership and Work Motivation toward Teacher's Discipline. Journal of Social Work and Science Education, $\quad 1(1), \quad 32-44 . \quad$ Retrieved from https://ejournal.karinosseff.org/index.php/jswse/article/view/8

Maryati, E., Fitria, H., \& Rohana, R. (2020). The Influence of Principal's Leadership Style and Organizational Culture on Teacher's Performance. Journal of Social Work and Science Education, 1(2), 127-139. Retrieved from https://ejournal.karinosseff.org/index.php/jswse/article/view/38

Rahmadoni, J. (2018). Isu Global Manajemen Pembiayaan Pendidikan di SD Indonesian Creative School Pekanbaru. Jurnal Manajemen, Kepemimpinan dan Supervisi Pendidikan 3(2), Juli-Desember 2018.

Ruslan, Lian, B., \& Fitria, H. (2020). The Influence o Principal's Situational Leadership and Teacher's Professionalism on Teacher's Performance. International Journal of Progressive Sciences and Technologies (IJPSAT), 20(1).

Sugiyono. (2015). Metode Penelitian Kombinas (Mix Methods) [Combined Research Methods]. Bandung: Alfabeta. 
Journal of Social Work and Science Education

Volume 1 (3) 2020

E-ISSN: 2723-6919 P-ISSN:2746-0827

Suyanto dan Abbas, M. S. (2001). Wajah dan Dinamika Pendidikan Anak Bangsa [The face and dynamics of the nation's children education]. Jakarta: Adicita Karya Nusa.

Syafaruddin. (2002). Manajemen Mutu Terpadu dalam Pendidikan Konsep Strategi, dan Aplikasi [Integrated Quality Management in Educational Concept, Strategy and Application]. Jakarta: PT. Gramedia Widiasarana Indonesia. 